\title{
The ILC's Draft Articles Before the 69th Session of the UNGA: A Reawakening?
}

\author{
Natalie Y. MORRIS-SHARMA* \\ Permanent Mission of the Republic of Singapore to the United Nations / Attorney-General's \\ Chambers, Singapore \\ natalie_morris_sharma@agc.gov.sg
}

\begin{abstract}
The treatment by states, at the 69th session of the UNGA, of the ILC's work on the responsibility of international organizations, the effects of armed conflicts on treaties, and the expulsion of aliens, offer some interesting points for reflection, particularly about the role of states in international law-making. This paper situates the UNGA's consideration of the draft articles before it within the context of the recent trends of the UNGA's commending of the ILC's draft articles to the attention of governments, and of its use of technical roll-overs. In this regard, the paper questions whether the UNGA's approach to the draft articles on the expulsion of aliens signals a reawakening of the UNGA. Against this backdrop, the paper also discusses the past practice of the UNGA when considering the draft articles of the ILC.
\end{abstract}

At the 69th session of the United Nations General Assembly (UNGA), the Sixth Committee considered the International Law Commission's (ILC) completed work on the responsibility of international organizations, the effects of armed conflicts on treaties, and the expulsion of aliens. The first two sets of draft articles had been on the agenda of the Sixth Committee since 20I I; and the third set of draft articles was before the Sixth Committee in its completed form for the first time that year.

For all three sets of draft articles, the ILC had made a two-stage recommendation: first, to take note of the draft articles and to annex them to the resolution; and second, to consider at a later stage the elaboration of a convention on the basis of the draft articles. For all three sets of draft articles, the UNGA deferred to a subsequent session its decision on the question of the form which the draft articles should take. However, whereas the UNGA adopted the recommendation of the ILC in respect of the draft

Advocate and Solicitor (Singapore) and called to the Bar (New York). Counsellor (Legal), Permanent Mission of the Republic of Singapore to the United Nations; Deputy Senior State Counsel, International Affairs Division, Attorney-General's Chambers. The views expressed herein are the views of the author and do not necessarily represent the views of the Government of Singapore. 
articles on the responsibility of international organizations and the draft articles on the effects of armed conflicts on treaties, the UNGA declined to do so in the case of the draft articles on the expulsion of aliens. ${ }^{\mathrm{I}}$

These preliminary observations offer some interesting points for reflection on two key trends in the UNGA's more recent treatment of the completed work of the ILC:

I. technical roll-overs; and

2. commending articles to the attention of governments before the UNGA has arrived at its decision on the final form the ILC draft articles should take.

Both these trends were continued in the resolutions on the responsibility of international organizations, and on the effects of armed conflicts on treaties. This was not the case with the resolution on the expulsion of aliens. This offers food for thought on the consideration by states of the work of the ILC, and the role of states in international law-making. In this regard, does the UNGA's approach to the draft articles on the expulsion of aliens mark a reawakening of the UNGA? Against this backdrop, this paper also discusses the past practice of the UNGA when considering the draft articles of the ILC.

\section{TRENDS IN THE UNGA'S TREATMENT OF THE ILC'S DRAFT ARTICLES}

\section{A. The Completed Work of the ILC}

The ILC's work has been the basis for a series of important international conventions which have promoted the codification and progressive development of international law. In most cases, the outcomes of the ILC's work have taken the form of draft articles. The draft articles have then gone before the UNGA for a decision on the final outcome of the work.

In the majority of cases (including the ILC's work on guidelines and other work that resulted in declaratory texts), the UNGA has taken a decision on the final outcome of the work within two to three years of the ILC's completion of work. ${ }^{2}$ Often, in discussions on the form which the ILC's draft articles should take, states have considered the consolidation of the draft articles in the form of a convention as useful only insofar as the draft articles are acceptable to a significant majority of states.

Thereafter, generally, the draft articles have been concluded as a convention either pursuant to an international conference of plenipotentiaries (e.g. the Vienna Convention on the Law of Treaties), or through further work by the UNGA, such as under the auspices of a working group or an ad hoc committee (e.g. as was respectively done with the Convention on the Law of Non-Navigational Uses of International

I. G.A. Res. 69/I26 (Io December 20I4), G.A. Res. 69/I25 (Io December 20I4), and G.A. Res. 69/II9 (Io December 20I4).

2. Notable exceptions to this were the ILC's work on the most-favoured-nation clause and on the draft code of offences against the peace and security of mankind. 
Watercourses and the UN Convention on Jurisdictional Immunities of States and Their Property).

\section{B. The Trend of Commending Articles to the Attention of Governments}

In recent years, the UNGA has deferred its decisions on the final outcome of the ILC's draft articles. Instead, the draft articles are commended to the attention of governments. There are a few aspects to this trend.

The first aspect involves the UNGA taking note of the draft articles, annexing them to the resolutions, and commending them to the attention of governments. This course of action was taken for the draft articles on the responsibility of international organizations and on the effects of armed conflicts on treaties, although this was expressed to be "without prejudice to the question of their future adoption or other appropriate action". ${ }^{3}$ This was also the course of action the UNGA took on the draft articles on the responsibility of states for internationally wrongful acts, on the consideration of prevention of transboundary harm from hazardous activities and allocation of loss in the case of such harm, as well as on the law of transboundary aquifers. ${ }^{4}$

In the UNGA's resolution on the responsibility of international organizations, the UNGA included a request to the United Nations Secretary-General (UNSG) to:

prepare an initial compilation of decisions of international courts, tribunals and other bodies referring to the articles and to invite Governments and international organizations to submit information on their practice in this regard, as well as written comments on any future action regarding the articles, and further requests the Secretary-General to submit this material well in advance of its seventy-second session. ${ }^{5}$

The language utilized here was similar to UNGA resolutions $59 / 35$ of 2 December 2004 and $65 / 28$ of 6 December 2010, where similar requests were made to the UNSG regarding the ILC's draft articles on state responsibility and on transboundary harm. This was not done in the cases of the draft articles on the effects of armed conflicts on treaties and on the expulsion of aliens.

The second aspect involves the UNGA referring in its resolutions to the "articles" (as opposed to the "draft articles") of the ILC. For both the draft articles on the responsibility of international organizations and on the effects of armed conflicts on treaties, the UNGA referred to the ILC's work as “articles” in its resolutions, rather than "draft articles". This was the case with the resolutions at the 66th UNGA as well as at the 69th UNGA. ${ }^{6}$ Again, this was in line with how the UNGA resolutions reflected the ILC's draft articles on state responsibility and on the prevention

3. G.A. Res. 69/I26 (Io December 20I4) and G.A. Res. 69/I 25 (Io December 20I4). The draft articles on the responsibility of international organizations were commended to the attention of international organizations as well.

4. Respectively, G.A. Res. 56/83 (I 2 December 200I), G.A. Res. 62/68 (6 December 2007), and G.A. Res. 63/I 24 (I I December 2008). Though not in the case of the UNGA's resolution on the draft articles on the expulsion of aliens, G.A. Res. 69/I I9 (IO December 20I4).

5. G.A. Res. 69/I26 (IO December 20I4).

6. G.A. Res. 66/100 (9 December 20II) and G.A. Res. 69/I26 (Io December 20I4); and G.A. Res. 66/99 (9 December 20II) and G.A. Res. 69/I 25 (IO December 20I4). 
of transboundary harm. ${ }^{7}$ On the other hand, the UNGA resolutions in relation to the draft articles on the expulsion of aliens and on the law of transboundary aquifers go against the grain of this trend. ${ }^{8}$

\section{The Trend of Technical Roll-Overs}

The deferrals by the UNGA at its 69th session, of its decisions on the question of the form for the draft articles that were before it, reveal yet another more recent trend of technical roll-overs.

There are a number of topics on which the ILC has completed draft articles but which continue to sit on the agenda of the Sixth Committee. At the 69th session of the UNGA, the responsibility of international organizations and on the effects of armed conflicts on treaties had been rolled over from the 66th session of the UNGA. Additionally, the ILC's draft articles on state responsibility, on the prevention of transboundary harm, and on the law of transboundary aquifers remain on the agenda of the Sixth Committee. ${ }^{9}$ In the case of the draft articles on the responsibility of states, the agenda item has been before the Sixth Committee every three years since 200I. The draft articles on the expulsion of aliens now join the list.

Not counting the draft articles on the expulsion of aliens, in all of the above-mentioned cases bar one, ${ }^{\text {IO }}$ the UNGA had adopted the ILC's dual-pronged recommendation to (i) take note of the draft articles in a resolution and to annex them to the resolution; and (ii) to consider, at a later stage, the elaboration of a convention on the basis of the draft articles. However, it is surprising that the Sixth Committee has not engaged in work or discussions to advance consideration of the agenda items in between the sessions of the UNGA when the agenda item is next slated to be taken up. The agenda item is not discussed at the UN until the next UNGA session, when it finds its way back on the agenda of the Sixth Committee, typically three years later. A trend of technical roll-overs has therefore emerged whereby subsequent resolutions simply repeat the decision of the UNGA to take note of the draft articles and to consider, at a later stage, the elaboration of a convention.

\section{The Dual-Pronged Approach}

The two trends-of commending articles to the attention of governments and of technical roll-overs—can be traced back to the UNGA's (and the ILC's) adoption of the dual-pronged approach. This approach facilitates the UNGA's deferral of its decision on the form of the ILC's draft articles to a later date.

7. For instance see, respectively, G.A. Res. 56/83 (I2 December 200I) and G.A. Res. 62/68 (6 December 2007).

8. See G.A. Res. 69/II9 (Io December 20I4) and, for the draft articles on the law of transboundary aquifers, see G.A. Res. 63/I 24 (I I December 2008), G.A. Res. 66/I04 (9 December 20I I), and G.A. Res. 68/I 8 (I6 December 20I3).

9. Also on the agenda is the ILC's work on the allocation of loss in the case of transboundary harm from hazardous activities, which is in the form of guiding principles.

Io. For the draft articles on prevention of transboundary harm, the ILC recommended the elaboration of a convention without specifying that this be considered at a later stage. 
What is usually cited when the dual-pronged approach is discussed in the literature is the ILC's recommendation to the UNGA on the draft articles on the responsibility of states for internationally wrongful acts. The ILC had engaged in substantial debate over the form which the draft articles should take, and eventually took a two-step approach on the recommendation of the open-ended working group. This accommodated both the Special Rapporteur's initial recommendation for the UNGA simply to take note of the text and to commend it to states, international courts, and tribunals, and the "dominant view" that preferred the process and form of a law-making convention. ${ }^{\text {II }}$

Less often referenced is how the UNGA had first taken such an approach in its resolution of 12 December 2000 on the ILC's draft articles on nationality of natural persons in relation to the succession of states. ${ }^{22}$ In the previous year, the ILC had recommended that the UNGA adopt the draft articles in the form of a declaration. During the meetings of the Sixth Committee, many states had expressed support for this recommendation. However, there were also others who preferred the conclusion of a convention. ${ }^{\mathrm{I}}$ It is likely that this divergence in views led the UNGA to not adopt the recommendation of the ILC, preferring instead to defer consideration of the elaboration of a convention on the basis of the draft articles. The agenda item was next taken up at the $55^{\text {th }}$ session of the UNGA in 2000. In the UNGA's resolution that year, the draft articles were taken note of and the text of the draft articles was annexed to the resolution. They were referred to not as "draft articles", but simply as “articles". ${ }^{\mathrm{I}}$

Since 2000, the UNGA has, in keeping with the ILC's recommendation, adopted the dual-pronged approach for the draft articles on the responsibility of international organizations, on the effects of armed conflicts on treaties, on the expulsion of aliens, on state responsibility, and on the law of transboundary aquifers-all of which remain on the agenda of the Sixth Committee. The UNGA also took the dual-pronged approach with the draft articles on prevention of transboundary harm, even though this was not the ILC's recommendation. ${ }^{\mathrm{I} 5}$

Many possible reasons as to why the UNGA has taken a dual-pronged approach in these cases may be proffered. While the individual reasons across the different draft articles may not always be the same, such an approach, broadly speaking, would have been a means of reaching a consensus on the agenda item in the face of divergent views amongst states over the question of the form the draft articles should take. Generally, such divergences have stemmed from differences in opinion over the acceptability of

I I. Report of the International Law Commission on the Work of its Fifty-third Session, U.N. G.A.O.R., 56th Sess., Supp. No. Io, UN Doc. A/56/Io (200I). Also see James CRAWFORD, Jacqueline PEEL, and Simon OLLESON, “The ILC's Articles on Responsibility of States for Internationally Wrongful Acts: Completion of the Second Reading” (200I) I 2 European Journal of International Law 963 at 970.

I2. G.A. Res. 55/I 53 (I 2 December 2000).

I3. Summary Record of the Meetings of the Sixth Committee, U.N. G.A.O.R., 54th Sess., U.N. Doc. A/C.6/ 54/SR/I 5 and A/C.6/54/SR/I7-28 (I999).

I4. The agenda item was then taken up at the 59th and 63rd sessions of the UNGA in 2004 and 2008 , respectively. It was only twelve years after the ILC had completed its work on the topic, during the 66th session of the UNGA in $201 \mathrm{I}$, that the UNGA decided not to continue having the item on their agenda.

I5. G.A. Res. 62/68 (6 December 2007). 
the balance struck by the text of the draft articles between the codification of existing legal rules and progressive development.

\section{KEY IMPLICATIONS OF THE TRENDS}

Combined with the trend of technical roll-overs, the trend of commending the ILC's draft articles to the attention of governments before a final decision is taken on their form has implications in respect of the role of states in international law-making. This is because they have resulted in the ILC's draft articles being essentially treated as treaties even when they are not. The implications of this are three-fold.

First, the ILC is potentially cast in the role of a legislator. ${ }^{16}$ The ILC's work, particularly on draft articles, necessitates careful balancing between elements of codification and elements of progressive development. Even though the ILC's work is informed periodically by inputs from governments, it is the ILC that considers the inputs and how best to incorporate them into its work. When the draft articles are taken note of, annexed to the UNGA's resolutions, and commended to the attention of governments before a decision is taken on their final form, it could be said that this represents an implicit endorsement by the UNGA of the ILC's authority in making certain trade-offs (and sometimes policy choices) in the course of their work.

The casting of the ILC in the role of legislator is further entrenched by the UNGA's reference to the draft articles merely as "articles". As Jacob Katz Cogan recently highlighted, "[t]he word 'draft' meant that the Commission's texts ... were preliminary ... The Commission was the originator, not the finalizer", and dropping the word "draft" when referencing the articles suggests that the UNGA believes that "the Commission's completed 'articles' can be (and should be) evaluated by governments, tribunals, and others on their own merits". ${ }^{17}$ The UNGA's requests to the UNSG to prepare initial compilations of the practice and decisions of governments and of courts, tribunals, and other bodies suggest that this supposition of the UNGA's attitude towards the draft articles of the ILC is not inaccurate. ${ }^{\mathrm{I} 8}$

Second, courts, tribunals, and other decision-making bodies to whom the articles are addressed may give undue authority to the draft articles. Courts, tribunals, and other decision-making bodies_-as well as practitioners who participate in the processes of such bodies-tend to rely on the draft articles as an authoritative statement of the law in the relevant field, without further critical analysis of the draft articles in view of their accompanying commentaries or the comments of states on the draft articles. The comments of states on the draft articles are important to appreciate because they are sometimes critical of the draft articles and reflect those aspects of the draft articles

I6. Sean D. MURPHY, “Codification, Progressive Development, or Scholarly Analysis? The Art of Packaging the ILC's Work Product” in Maurizio RAGAZZI, ed., Responsibility of International Organizations: Essays in Memory of Sir Ian Brownlie (Leiden: Koninklijke Brill NV, 2013), 29-40 at 35.

I7. Jacob Katz COGAN, “The Decline of 'Drafts"” (20I4) i I International Organizations Law Review I at 2-3. Also see Jacob Katz COGAN, “The Changing Form of the International Law Commission's Work” in Roberto VIRZO and Ivan INGRAVALLO, eds., Evolutions in the Law of International Organizations (Leiden: Koninklijke Brill NV, 20I 5), 275.

I 8. For instance, G.A. Res. 69/I 26 (Io December 20I4), G.A. Res. 59/35 (2 December 2004), and G.A. Res. 65/28 (6 December 2010). 
which do not enjoy consensus. The possibility of undue authority being conferred on the draft articles was one of the three phenomena that David Caron identified when he examined the ILC's recommendation on the draft articles on state responsibility. Caron cited his study of the attribution practice of the Iran-United States Claims Tribunal, and how he was surprised to find that the Tribunal tended to merely accept the draft articles on states' responsibility as given. ${ }^{\text {I9 }}$

The problem of not giving undue authority to the draft articles is one that is not easy to resolve. Many threads are required to weave together the often rich tapestry of the draft articles. The reception by states of the draft articles is contained in (or perhaps more accurately described as "scattered across") written inputs to the ILC and statements orally delivered at the UNGA. States also provide comments while the draft articles are being worked on by the ILC, and after the ILC has completed its work. The statements made at the UNGA can be found in the summary reports of the meetings; they are captured according to the order in which the statements are delivered, not necessarily by the ILC topic concerned, and certainly not according to the individual articles within each set of draft articles.

The already difficult task of tracking the reception by states of the draft articles is compounded by each successive roll-over of the UNGA's consideration of the form of the draft articles. Each year a set of draft articles is on the agenda, more statements have to be woven together. The task is not small when one considers that the UNGA's deferral of its decisions on the form of the ILC's various draft articles have been for not inconsiderable lengths of time. For example, the draft articles on the responsibility of states have been on the agenda of the Sixth Committee for fourteen years, and the draft articles on the law of transboundary aquifers for seven years.

Third, states gradually relinquish their role in law-making. With each technical roll-over, and particularly in the light of the preceding two implications discussed above, states cede more of their function in law-making. The deferral of a decision on the final form of the ILC's draft articles is often to allow for a period of reflection. However, without much-and sometimes without any-discussion between the sessions when the agenda item is to be taken up, states do not have the opportunity to advance their own thinking or to work with other states to arrive at a consensus on the form of the ILC's draft articles.

\section{A REAWAKENING OF THE UNGA?}

\section{A. Reception of the Draft Articles on the Expulsion of Aliens}

Conceivably, it was an awareness of these implications that led to the UNGA's treatment of the ILC's draft articles on the expulsion of aliens in resolution 69/I I9 of Io December 20I4. Of the three UNGA resolutions on the completed work of the ILC that year, the negotiations for this resolution were the last to conclude.

The majority of states were not in favour of the draft articles being articulated as a convention. A few were not even in favour of further work on the topic. This is because,

I9. David D. CARON, “The ILC Articles on State Responsibility: The Paradoxical Relationship Between Form and Authority" (2002) 96 American Journal of International Law 857 at 858,867-8. 
from their perspective, the draft articles did not maintain the careful balance between promoting and protecting human rights and a state's sovereignty over its borders. There was also the view that the draft articles did too much in the way of progressive development. Accordingly, some states held the view that the draft articles would be better off as guidelines. Other states were open to considering the possible elaboration of a convention on the basis of the draft articles at a later stage, but even these statements were tentatively framed. A number of states were disenchanted by the failure of the ILC to take into account the previous comments of states. ${ }^{20}$

In the resolution on the expulsion of aliens, the UNGA decided to include consideration of the ILC's two-step recommendation in the agenda of its $72 \mathrm{nd}$ session. Notably, in prefacing this decision, instead of the more regular formulation of commending the draft articles to the attention of governments without prejudice to the question of their future adoption or other appropriate action, the resolution merely took note of the recommendation of the ILC in this regard. The articles were qualified as "draft articles" throughout the resolution. The draft articles were neither commended to the attention of governments nor were they annexed to the resolution. ${ }^{2 \mathrm{I}}$ In this way, the UNGA bucked the first trend.

It remains to be seen if the UNGA will also buck the second trend of technical roll-overs-not just for the draft articles on the expulsion of aliens, but also for the other draft articles that remain on the UNGA's agenda.

\section{B. Avoiding Technical Roll-Overs: Recalling Possible Approaches}

Successive technical roll-overs are not a solution to the problem of a lack of consensus on the final form the draft articles should take. Instead, a study of the past practice of the UNGA provides certain inspiration for possible ways to encourage states to tackle the question of the final form of the draft articles.

\section{Convening a working group or informal consultations: means and methods}

The convening of informal consultations was the Sixth Committee's approach to finding consensus on the ILC's work on the status of the diplomatic courier and the diplomatic bag not accompanied by diplomatic courier. The informal consultations were convened to "study" the draft articles and the draft optional protocols, as well as "how to deal further with those draft instruments". ${ }^{22}$ Further, the UNGA's resolutions on the draft articles in I990 and I995 noted the reports of the facilitators of the informal consultations. ${ }^{23}$ This indicated that the draft articles were under active consideration by the Sixth Committee. In addition, informal consultations were held at the $45^{\text {th }}$, 46th, and $47^{\text {th }}$ sessions, before the UNGA decided at its 5 oth session to not turn the draft articles into a convention. ${ }^{24}$

20. Summary Record of the Meetings of the Sixth Committee, U.N. G.A.O.R., 69th Sess., U.N. Doc. A/C.6/ 69/SR/I9-22 (20I4).

2I. G.A. Res. 69/I I9 (Io December 2014).

22. G.A. Res. 44/36 (4 December 1989).

23. G.A. Res. 45/43 (28 November I 990) and G.A. Res. 50/4I6 (I I December I 995).

24. G.A. Res. 44/36 (4 December I989), G.A. Res. 45/43 (28 November I990), G.A. Res. 46/57 (9 December I99I), and G.A. Res. 50/4I6 (I I December I995). 
The annual consideration of the draft articles from I990 to I 992 likely played a role in the ability of states to advance their work. In contrast, the three-year inter-sessional period, a relatively recent practice, has, anecdotally, contributed to an inability on the part of states' representatives to maintain momentum on the consideration of the relevant draft articles.

The convening of a working group to find consensus on the appropriate action to be taken on the ILC's work was the format taken more recently, since 2010 , for the Sixth Committee's examination of the draft articles on state responsibility and on diplomatic protection, ${ }^{25}$ but this has not yielded much progress. Of greater interest are the working groups which were convened when the draft articles on the jurisdictional immunities of states and their property were before the Sixth Committee. In that case, as with the convening of the working group to elaborate a framework convention on the law of non-navigational uses of international watercourses, the objectives of the working groups were not to find consensus on the final form of the draft articles, as states were generally supportive of the ILC's recommendation to discuss the articles at a diplomatic conference. Nonetheless, there are some valuable learning points.

For the draft articles on jurisdictional immunities, the ILC had in I99I recommended the convening of an international conference of plenipotentiaries to examine the draft articles and conclude a convention on the topic. In the same year, the UNGA decided to establish at its $47_{\text {th }}$ session an open-ended working group of the Sixth Committee. ${ }^{26}$

It was not until 2004 that the UNGA adopted the United Nations Convention on Jurisdictional Immunities of States and Their Property. However, the path to the adoption of the Convention was marked by active consideration of the draft articles, rather than by effectively suspending substantive discussions on the draft articles with technical roll-overs of the agenda item.

During the thirteen years from I99I to 2004, the item was on the agenda every year save for the 5oth and 5ist sessions of the UNGA in 1995 and $1996 .{ }^{27}$ As mentioned above, the annual consideration of the draft articles conceivably played a role in enabling states' representatives to maintain momentum on the consideration of the relevant draft articles.

Further, in the years that the item was on the agenda, the Sixth Committee worked using a series of different formats. First, open-ended working groups of the Sixth Committee were convened to examine issues arising out of the draft articles and the question of the convening of an international conference to conclude a convention. ${ }^{28}$ Subsequently, once the working groups had identified issues for which further comments and recommendations of the ILC would be useful, the ILC was invited to present preliminary comments regarding the outstanding substantive issues related to the $\mathrm{draft}$

25. For the draft articles on state responsibility, see G.A. Res. 62/6I (6 December 2007), G.A. Res. (6 December 20I0), and G.A. Res. 68/I04 (I6 December 20I3); and for the draft articles on diplomatic protection, see G.A. Res. 62/67 (6 December 2007), G.A. Res. 65/27 (6 December 2010), and G.A. Res. 68/II3 (I6 December 20I3).

26. G.A. Res. 46/55 (9 December I99I).

27. At the 49th session of the UNGA in I994, the UNGA decided that they would resume consideration on the topic at its 5 2nd session.

28. G.A. Res. 46/55 (9 December I99I) and G.A. Res. 53/98 (8 December I998). 
articles. After receipt of the report of the ILC's working group, the Sixth Committee at its $55^{\text {th }}$ session decided to establish an Ad Hoc Committee on Jurisdictional Immunities of States and Their Property, to "further the work done, consolidate areas of agreement and resolve outstanding issues with a view to elaborating a generally acceptable instrument". ${ }^{29}$ The Ad Hoc Committee was reconvened, on the dates specified in the relevant resolution, each year until the UNGA adopted the UN Convention on Jurisdictional Immunities of States and Their Property in 2004. ${ }^{30}$

In this way, there was a process to engage states in the consideration of the draft articles each year the item was on the agenda. Discussions were differently structured as the work evolved. Mandates were articulated and adjusted as deliberations developed. Specific dates for meetings were set. Recent developments relating to state practice and legislation since the adoption of the draft articles were considered. Additionally, the Sixth Committee's request in I 998 to the ILC to present comments facilitated a furthering of the dialogue between the ILC and governments on the draft articles, particularly in the light of relevant case-law and how the issues addressed or impacted by the draft articles had evolved. Moreover, it is plausible that the active consideration by the Sixth Committee of the draft articles sent a clear signal about their draft status.

\section{Adopting different formulae to consider the topic further}

Also available to the UNGA is the option of taking the topic off the agenda until states are ready to consider the topic further. Under this approach, the UNGA would adopt different formulae to convene a conference or for subsequent discussions of the topic. In other words, the agenda item would not be tabled unless there is an expression of interest by a threshold number of states. Such expression of interest may be construed, for instance, from states which comment on or which request further consideration of the draft articles, or from states which communicate a willingness to co-operate in a conference to turn the draft articles into a convention. This was done for the ILC's work on the fundamental rights and duties of states, on nationality including statelessness, and on the nationality of natural persons in relation to the succession of states.

In respect of the ILC's work on the fundamental rights and duties of states, the ILC did not make a recommendation to the UNGA, but simply submitted the draft declaration to the UNGA and stated that it was for the UNGA to decide on the further course of action which should be taken. The UNGA took note of the draft declaration and resolved to transmit the draft declaration, together with the documentation relating thereto, to states for their comments and suggestions, including on any further action to be taken on the draft declaration. ${ }^{3 \text { I }}$ Subsequently, the UNGA decided that the number of states which had given their comments and suggestions was too small to form the basis of any definite decision on the draft declaration, and decided to postpone

29. G.A. Res. 55/I 50 (I 2 December 2000).

30. G.A. Res. 56/78 (I2 December 200I), G.A. Res. 57/I6 (I9 November 2002), and G.A. Res. 58/74 (9 December 2003).

3I. G.A. Res. 375 (IV) (6 December 1949). 
consideration of the matter "until a sufficient number of States have transmitted their comments and suggestions". ${ }^{32}$ The UNGA also decided to "undertake consideration as soon as a majority of the Member States have transmitted [their comments and suggestions]".33

In respect of the draft articles on nationality including statelessness, the UNGA considered that the Economic and Social Council had approved the principles of the two draft conventions, and that fifteen states had provided comments on the work of the ILC on the topic. The UNGA identified "at least twenty States" as the threshold number of states which were required to communicate to the UNSG their willingness to co-operate in an international conference of plenipotentiaries to conclude a convention before such a conference would be convened. ${ }^{34}$

For the draft articles on the nationality of natural persons in relation to the succession of states, the UNGA decided that it would only return to considering the draft articles if a state requested it, and set the threshold number of one state for further consideration of the topic. ${ }^{35}$

\section{Additional comments}

The above options were means which the UNGA had previously employed to deal with the draft articles completed by the ILC. These means either ensured active consideration or suspended consideration by the Sixth Committee of the draft articles. In this way, a clear signal was sent about the status of the articles as drafts.

These options remain useful for the UNGA to think about moving forward, so that when considering how to tackle the question of the final form the draft articles should take, work processes can be designed to better obviate the prospect of successive roll-overs of the agenda item for several years.

To be sure, there have already been some informal efforts at the UN to stimulate discussions on specific works of the ILC. These have been ad hoc arrangements, at the initiative of individual states. Some have been one-off panel discussions without subsequent follow-through. Not all have had a broad reach across states. As such, while laudable, they are not sufficient in and of themselves.

Through the convening of a working group or informal consultations, or adopting different formulae for subsequent consideration of the topic, states could be incentivized by the resolution to (further) develop their thinking on the draft articles inter-sessionally. Hopefully, this could also promote an exchange of views between states over their support for or concerns over the draft articles. Such an exchange would be helpful to understanding the landscape of states' views on the draft articles, engaging states that are typically silent during the Sixth Committee plenary sessions on

\footnotetext{
32. See Report of the International Law Commission on the Work of its First Session, U.N. G.A.O.R., 4th Sess., Supp. No. Io, UN Doc. A/CN.4/I 3 and Corr. I-3 (I949), 286. Seventeen states had provided their comments and suggestions to the ILC on the topic.

33. G.A. Res. 596 (VI) (7 December I95I).

34. G.A. Res. 896 (IX) (4 December I954).

35. G.A. Res. 66/92 (9 December 20II).
} 
the ILC's work, and identifying the aspects of the draft articles that may be problematic so that options can be framed for the way forward.

\section{CONCLUSION}

The current trends of commending the draft articles completed by the ILC to the attention of governments and of technical roll-overs have manifested themselves for close to fifteen years and are not without their implications. In particular, the ILC (as well as national and international courts and tribunals and other decision-making bodies) has had a greater influence on international law-making than would otherwise have been the case. By the same token, states have gradually relinquished their role in law-making.

It is likely that it was the awareness of these implications that led the UNGA at its 69th session to buck the first trend of commending the draft articles on the expulsion of aliens to the attention of governments. In the same spirit, it is possible that the UNGA will also put the pieces in place to avoid lapsing into a series of technical roll-overs when these draft articles are again brought before it at its $72 \mathrm{nd}$ session. This may influence the UNGA's treatment of the draft articles on the responsibility of international organizations and on the effects of armed conflicts on treaties, which will also be before it at that session. It is even possible that the UNGA may also re-evaluate its approach at its 7 Ist session, when the draft articles on the responsibility of states, on diplomatic protection, on transboundary harm, and on the law of transboundary aquifers are slated to be discussed. In this context, it is useful to reflect on the past practice of the UNGA when considering how to confront the question of the final form of the draft articles of the ILC such that technical roll-overs do not occur in the way that they have come to do today. 